\title{
CREDITOR CONTROL AND CONFLICT IN CHAPTER 11
}

\author{
Kenneth M. Ayotte and Edward R. Morrison ${ }^{1}$
}

\begin{abstract}
We analyze a sample of large privately and publicly held businesses that filed Chapter 11 bankruptcy petitions during 2001. We find pervasive creditor control. In contrast to traditional views of Chapter 11, equity holders and managers exercise little or no leverage during the reorganization process. 70 percent of CEOs are replaced in the two years before a bankruptcy filing, and few reorganization plans (at most 12 percent) deviate from the absolute priority rule to distribute value to equity holders. Senior lenders exercise significant control through stringent covenants, such as line-item budgets, in loans extended to firms in bankruptcy. Unsecured creditors gain leverage through objections and other court motions. We also find that bargaining between secured and unsecured creditors can distort the reorganization process. A Chapter 11 case is significantly more likely to result in a sale if secured lenders are oversecured, consistent with a secured creditor-driven fire-sale bias. A sale is much less likely when these lenders are undersecured or when the firm has no secured debt at all. Our results suggest that the advent of creditor control has not eliminated the fundamental inefficiency of the bankruptcy process: resource allocation questions (whether to sell or reorganize a firm) are ultimately confounded with distributional questions (how much each creditor will receive) due to conflict among creditor classes.
\end{abstract}

Two themes dominate traditional accounts of Chapter 11 reorganization. First, managers or equity holders, or both, control the process (Bradley and

1 Northwestern University School of Law and Columbia Law School, respectively. We received helpful comments from Barry Adler, John Armour, Albert Choi, Jesse Fried, Scott Hemphill, Richard Hynes, Juliet Kostritsky, Robert Rasmussen, James Spindler, and Oren Sussman; from workshop participants at Bonn, Case Western, Chicago, Columbia, DePaul, Northwestern, Oxford, University of Pennsylvania, University of Southern California, University of Virginia, Unversity of Utah, and Yale; and from participants at the following conferences: Conference on Commercial Law Realities (University of Texas), Conference on Empirical Legal Studies (New York University), Triangle Law and Economics Conference (Duke/University of North Carolina), Workshop on Private and Public Resolution of Financial Distress (Vienna Graduate School of Finance), European Summer Symposium in Financial Markets, and Conference on the Changing Nature of Credit Markets (SIFR). We thank Charles Alivosetti, Ariana Cooper, James Judah, Zeev Kirsh, Christopher Mellem, Nathan Rehn, Christina Schutz, Jeong Song, Robert Tennenbaum, and David Zylberberg for superb research assistance. 
Rosenzweig 1992; Bebchuk and Chang 1992; Adler 1993; Schwartz 1997). This is made possible by debtor-friendly features of the U.S. Bankruptcy Code and judges who are passive or biased in favor of keeping an existing business intact. Exploiting the court's protection, managers can entrench themselves and equity holders can extract concessions from creditors. As a result, courts may permit reorganizations of firms that should be liquidated. The second theme, usually implicit in the literature, is that creditors act as a unified constituency, usually agitating for quick liquidation. Together, these traditional themes continue to influence the academic literature in many areas related to financial distress. ${ }^{2}$

A recent wave of literature by academics and practitioners suggests that these themes-at least in large corporate bankruptcies-are outdated (Baird and Rasmussen 2002; Skeel 2003; Warren and Westbrook 2003; Miller and Waisman 2004; Adler, Capkun, and Weiss 2008). During the past decade, creditors with senior, secured claims have come to dominate the Chapter 11 process. Much of this creditor control is exercised through secured lines of credit, which are extended to the firm both before and after it files a bankruptcy petition. As Skeel (2004) and Baird and Rasmussen (2006) have shown, these lines of credit limit the debtor's access to cash and impose strict requirements on business activity. Baird and Rasmussen (2003) argue that, due to this control, we have seen a dramatic increase in the proportion of Chapter 11 cases that result in piece-meal liquidation or a going-concern sale. As LoPucki $(2003,648)$ has shown, going-concern sales accounted for less than 20 percent of Chapter 11 cases filed by large, publicly traded firms during the 1980s. In 2002, they accounted for about 75 percent of the cases.

In addition to shifting the focus away from equity and managerial control in Chapter 11 bankruptcies, the recent literature also directs attention away from the unified, single-creditor framework. The onset of senior, secured creditor control raises issues of potential creditor conflict between senior and junior classes of debt. As senior lenders have obtained control through pre- and post-petition financing, junior lenders have used claims trading, committees, and other tactics to gain leverage over the reorganization

2 For example, Acharya, John, and Sundaram (2005) compare the "equity-friendly" U.S. system and the "creditor-friendly" U.K. system. Structural models used in bond pricing typically assume a single class of debt, with shareholders extracting surplus from the creditor in workouts or in bankruptcy. Examples include Francois and Morellec (2004) and Broadie, Chernov, and Sundaresan (2007). 
process (Fortgang and Mayer 1990; Tung 1996; Partnoy and Skeel 2007). Junior lender activism has increased as hedge funds and other investors have purchased the claims of bondholders and similarly dispersed creditors who, in the past, did not participate actively in the bankruptcy process (Goldschmid 2005; Fisher and Buck 2007).

Our paper has two objectives. The first is to provide systematic evidence on the validity of these new themes-creditor control and creditor conflict-in large, corporate Chapter 11 cases. Existing evidence is largely anecdotal, raising doubts whether a new perspective on the bankruptcy process is necessary. Our second objective is to identify the effects of creditor control and conflict on bankruptcy outcomes, such as the decision to reorganize or sell the firm. Prior theoretical literature shows that managercreditor and equity-creditor conflict can lead to asset misallocation during the reorganization process. We use our database to investigate whether a different kind of conflict—senior creditors versus junior creditors-distorts outcomes in bankruptcy cases. As with most scholarship in this area, however, we focus exclusively on dynamics during the bankruptcy process. We do not analyze creditor and debtor behavior during the months preceding a bankruptcy filing. Because of this, we cannot fully evaluate the efficiency consequences of control and conflict in bankruptcy. Greater creditor control, for example, could affect the behavior of equity holders and managers prior to bankruptcy. Managers might invest in wasteful strategies to delay a filing, as Adler, Capkun, and Weiss (2008) argue.

We investigate creditor control and conflict using a unique database of Chapter 11 filings by large publicly traded and privately held corporations. These data provide strong evidence that the traditional view of Chapter 11 bankruptcy is outdated. We find that 70 percent of CEOs are replaced within the two years preceding the bankruptcy filing. This represents a sharp increase over comparable figures reported in previous studies and suggests strongly that Chapter 11 does not provide a safe harbor for entrenched managers. Additionally, we find that few reorganization plans (at most 12 percent) deviate from the absolute priority rule by distributing value to equity holders even though creditors have not been paid in full. In at least 82 percent of the cases, equity holders received nothing.

We also find strong evidence that senior creditors obtain substantial control through their loan agreements with distressed debtors. 75 percent of the bankrupt corporations obtained senior secured financing prior to entering bankruptcy. In 97 percent of these cases, the loans were secured by 
a lien on all of the corporation's assets. After entering bankruptcy, debtors obtained post-petition financing in 76 percent of the cases, and in 92 percent of these cases the loans were secured by liens on all of the firms' assets. More importantly, the vast majority of the loans contained covenants imposing line-item budgets, profitability targets, or deadlines for submitting a plan of reorganization. The lender was generally free to seize collateral unilaterally—without first seeking court approval—if the corporation violated any of these covenants.

Although senior secured lenders appear to exert significant control through loan documents, we also find evidence of frequent creditor conflict. Junior creditors, acting through a creditors' committee, filed objections in more than 50 percent of the cases. Senior creditors often filed objections as well. In 46 percent of the cases, pre- or post-petition senior creditors objected to actions proposed or taken by the corporations' managers.

Finally, our analysis shows that creditor conflict has an important effect on bankruptcy outcomes. We find a statistically significant, non-monotonic relationship between the ratio of secured debt-to-assets and the resolution of the case. When secured creditors are undersecured (their claims exceed the value of the firms' assets, making them the approximate residual claimants) and when there is no secured debt at all (making the unsecured creditors the approximate residual claimants), the cases are relatively long and more likely to result in a traditional reorganization. ${ }^{3}$ But when secured creditors are oversecured (their claims are worth less than the value of the firms' assets), we expect to see-and do see-a different pattern. In these cases, theory predicts that creditor conflict is likely to be most pronounced. Oversecured creditors will prefer an immediate resolution. Their claims may be paid in full during a quick sale, even if the firm is sold for less than its fundamental value; any delay-especially a lengthy reorganization process - could hurt them if firm value deteriorates over time. Unsecured creditors, on the other hand, will prefer a reorganization if it lengthens the case. If firm value improves over time, these creditors keep most of the upside; if value declines, they share any losses with senior creditors. Consistent with this theory, we find that cases are more likely to result in a sale when secured creditors are oversecured than when the firm has no secured debt or has an approximate

3 This is consistent with the idea that, in the absence of conflict, creditors value the reorganization process as a means of alleviating liquidity problems. See Shleifer and Vishny (1992) and Gertner and Picker (1992). 
residual claimant, such as an undersecured creditor. These results support the hypothesis that senior creditors have substantial power to control bankruptcy outcomes and that they exercise this power more vigilantly when delay poses a greater risk to the value of their claims. ${ }^{4}$

Our findings show that creditor conflict distorts economic outcomes in bankruptcy. We cannot, however, evaluate the efficiency loss associated with this conflict. Creditor conflict might yield inefficiently quick sales in some cases and inefficiently slow sales or reorganizations in others.

Our paper is organized as follows. Section 1 reviews the prior literature, Section 2 describes our database, Section 3 presents summary statistics, and Section 4 sets out simple measures of creditor control and conflict. In Section 5, we test the effects of control and conflict on the reorganization process. Section 6 concludes.

\section{PRIOR LITERATURE}

The general phenomenon of creditor control has been the topic of numerous studies, some of them empirical, such as Gilson and Vetsuypens (1994). The dynamics of creditor conflict have received comparatively less attention.

With respect to creditor control, several papers have documented the frequency of in-bankruptcy lines of credit (DIP financing) during the 1990s. In a study of publicly traded firms that entered Chapter 11 proceedings between 1988 and 1997, Dahiya et al. (2003) found DIP financing in 31 percent of the cases, rising to 48 percent in the mid-1990s. In a similar study, Carapeto (2003) observed DIP financing in 41 percent of cases, with a high of 67 percent in 1996. ${ }^{5}$ Both studies found DIP financing more common in cases involving larger firms and in prepackaged cases. A prepackaged case is one in which the debtor secured approval for its reorganization plan from a super-majority of creditors before the firm actually filed its Chapter 11 petition. Dahiya et al. (2003) and Carapeto (2003) also report that, relative to debtors without DIP financing, those with financing had faster cases and were more likely to reorganize or merge with another firm than undergo piecemeal liquidation. Carapeto, however, also found that the probability

4 Previous work in a different institutional setting (Swedish bankruptcy auctions) found a similar non-monotonic pattern, relating the senior debt-to-assets ratio and the probability of liquidation versus a sale-back to management. See Stromberg (2000).

5 Other studies include Dhillon, Noe, and Ramirez (1996), Elayan and Meyer (2001), and Chatterjee, Dhillon, and Ramirez (2004). 
of liquidation was higher when the DIP financing gave the lender a security interest that was senior to existing secured debts (a "priming lien").

These papers are important but tell us little about the terms of DIP financing and why it is an effective tool of creditor control. Carapeto (2003) addresses this issue in part, showing that one characteristic of DIP financing - whether the lender receives a priming lien-has an important effect on outcomes. We do not know, however, whether other characteristics of DIP financing matter as well. ${ }^{6}$

The closest papers to ours in this respect are contemporaneous working papers by Bharath, Panchapegasan, and Werner (2007) and McGlaun (2007). Bharath, Panchapegasan, and Werner investigate the determinants of absolute priority rule (APR) violations. An APR violation occurs when a reorganization plan distributes value to junior interests even though senior interests have not been paid in full. An APR violation in favor of equity holders can be viewed as evidence of manager or equity holder control. Similar to our study, Bharath, Panchapegasan, and Werner (2007) find that APR violations were less common during the early 2000s than they were during the 1980s. They hypothesize-and present supporting evidence-that APR violations declined during the 1990s and 2000s because creditors exercised greater control, via DIP financing and other tools, during the same period.

McGlaun (2007) uses bankruptcy court data from PACER to document covenants in senior loan agreements and investigate the influence of senior lenders on bankruptcy outcomes. He finds, as do we, a relationship between the senior debt-to-assets ratio and case disposition. The relationship is consistent with a desire among senior creditors to resolve cases more quickly when their claims are more at risk. But McGlaun does not find the statistically significant, non-monotonic relationship we document in section 5 below.

CEO turnover during bankruptcy has also received attention as a measure of creditor control. Carapeto (2003) finds that turnover is higher among firms that receive DIP financing, consistent with the notion of creditor control. Bharath, Panchapegasan, and Werner $(2007,22)$ find that turnover rates in bankruptcy increased 65 percent between 1990 and the early 2000s. Among entrenched managers-those with significant equity holdings - the turnover rate rose more than 200 percent, a change they attribute to increased creditor control during the same period.

6 Chatterjee, Dhillon, and Ramirez (2004) catalogue the covenants in DIP loans to publicly traded corporations that filed Chapter 11 petitions between 1988 and 1997. Although they compare these covenants to those in other credit agreements, the authors do not assess the effect of these covenants on bankruptcy outcomes. 
Several scholars have examined CEO turnover preceding a bankruptcy filing. Bernstein (2006) finds high levels of turnover during 2001. Among publicly traded firms in bankruptcy, about 43 percent of the CEOs were replaced within the two years preceding the filing. Oddly, this turnover rate is lower than rates estimated by other scholars using data on cases filed during the early 1980s, the heyday of management control. Gilson (1989), for example, studied 69 publicly traded firms that entered Chapter 11 proceedings between 1979 and 1984 and estimated a turnover rate equal to 55 percent during the two years preceding the bankruptcy filing. A similar rate, equal to 53 percent, can be derived from the work of LoPucki and Whitford (1994, 723-36), who studied the 43 largest publicly held corporations that filed Chapter 11 petitions between 1979 and 1988 and successfully reorganized. ${ }^{7}$

\section{DATA}

We collected data on all corporate bankruptcies listed in the Bankruptcy Datasource "Public and Major Company Database" during the latter half of $2001 .^{8}$ This datasource is commonly used in corporate finance and is attractive because it includes filings by both publicly traded and privately held firms. We chose the latter half of 2001 because data for earlier periods are highly incomplete, and at the beginning of this project we worried that we might encounter a censoring problem if we studied post-2001 years because many cases would still be ongoing. ${ }^{9}$

Our initial sample included 153 cases, listed in Appendix $B^{10}$. For each case, we gathered information about the parent company and its subsidiaries in

7 We calculated this rate using the data reported in Table 4 of LoPucki and Whitford (1994). The time window used by LoPucki and Whitford begins 18 months prior to the Chapter 11 filing, which is slightly shorter than that used by Gilson (1989). Turnover rates rise dramatically, of course, when the window is extended to include post-petition events. LoPucki and Whitford, for example, estimate a turnover rate equal to $91 \%$ based on a window beginning 18 months prior to filing and ending 6 months after plan confirmation. $I d$, at 723. Using a similar windowbeginning 2 years prior to filing and ending at plan confirmation-Brian Betker (1995) observed a turnover rate equal to 75 percent in a sample of 75 firms listed in the Bankruptcy Data Source. See Betker (1995) for additional studies of CEO turnover in financially distressed firms.

8 The list of firms is available at http://www.bankruptcydata.com/findabrtop.asp. This database includes bankruptcy filings by (a) all publicly traded corporations and (b) privately held corporations that issued public debt or were "deemed significant and newsworthy."

9 One of the most popular courts, the Bankruptcy Court for the District of Delaware, began posting images in July 2001.

10 We excluded Enron's case due to its unique complexity. 
bankruptcy. Our data sources were PACER, SEC filings, and the Bankruptcy Datasource. PACER is our primary resource. Every bankruptcy court maintains a PACER website, which contains the docket sheet for and, often, images of all documents filed in a bankruptcy case. Document images were unavailable or incomplete in many cases, so the number of observations varies in the following statistical analysis. For some measures of interest, we have complete data for all 153 cases; for others, we have complete data for only a subset. We did not try to supplement the incomplete PACER materials by, for example, collecting physical documents from the bankruptcy courts. That would have been prohibitively costly in light of the time required to hand-collect and code the materials available on PACER.

In most of the analysis that follows, we rely on information contained in court schedules because they offer up-to-date information about the firm's capital structure when it files, including data on secured debt. Comparable information is often unavailable in SEC filings.

\section{SUMMARY STATISTICS}

Tables 1 and 2 present summary information about the businesses and their experiences in bankruptcy. We see a dramatic change in capital structures as firms approach bankruptcy. Table 1 presents statistics on asset and debt holdings before and after the bankruptcy filings. The pre-bankruptcy statistics for publicly-held firms are based on the most recent Compustat data during the two year period preceding the bankruptcy filing. Before filing for bankruptcy, the median public firm reported assets worth $\$ 151$ million, debt of about $\$ 112$ million, and secured debt equal to $\$ 6$ million. The bankruptcy schedules present a different capital structure: the median public firm reported assets worth $\$ 98$ million and secured debt of $\$ 67$ million. Thus, we see a 35 percent drop in asset value and an eleven-fold increase in secured debt among public companies during the one to two years preceding the bankruptcy filing.

Ninety percent of the firms entered bankruptcy with secured debt. Table 2 presents important variation in the value of secured debt relative to assets. In 39 percent of the cases, the total value of secured claims was equal to less than 50 percent of asset value; in 28 percent of the cases, it ranged between 50 and 100 percent of asset value; and in 22 percent of the cases, secured claims exceeded the value of the company. In other words, secured creditors were undersecured in over a fifth of the cases. A similar pattern emerges when we compare, as the 
Table 1. Capital Structure of Public and Private Companies

\begin{tabular}{|l|c|c|c|c|c|c|}
\hline & Obs. & Mean & SD & Median & Min & Max \\
\hline Assets (millions) \\
\hline Before, public & 99 & 662.8 & $1,447.8$ & 151.2 & 0.9 & $10,255.0$ \\
\hline At filing, public & 71 & 621.5 & $1,981.8$ & 98.1 & 0.2 & $15,859.9$ \\
\hline At filing, private & 18 & 66.7 & 98.3 & 35.3 & 1.6 & 381.4 \\
\hline Debt (millions) \\
\begin{tabular}{|l|c|c|c|c|c|c|}
\hline Before, public & 99 & 574.1 & $1,256.8$ & 111.6 & 0.6 & $8,704.8$ \\
\hline Secured Debt (millions) & 96 & 147.0 & 477.7 & 6.0 & 0.0 & $4,228.9$ \\
\hline Before, public & 71 & 233.3 & 528.6 & 67.3 & 0.0 & $3,986.8$ \\
\hline At filing, public & 71 & 22.2 & 38.1 & 4.2 & 0.0 & 126.4 \\
\hline At filing, private & 18 &
\end{tabular}
\end{tabular}

Note: Data for parents and subsidiaries are reported on a consolidated basis. If subsidiaries did not enter bankruptcy with the parent company, their financial information is not reflected in the at-filing statistics reported here. Pre-bankruptcy data are taken from SEC filings by publiclytraded corporations. At-filing data are taken from bankruptcy schedules. Because these schedules are incomplete, the number of observations for public firms is smaller at filing (71) than before bankruptcy (99).

Table 2. Capital Structure of Parent and Subsidiaries, Before and At Filing

\begin{tabular}{|c|c|c|}
\hline & $\begin{array}{l}\text { Total Secured Debt } \\
\text { (Proportion) }\end{array}$ & $\begin{array}{l}\text { Secured Debt Held by } \\
\text { Largest Creditor } \\
\text { (Proportion) }\end{array}$ \\
\hline \multicolumn{3}{|c|}{ No Secured Debt } \\
\hline Before & 0.35 & \\
\hline At Filing & 0.10 & \\
\hline \multicolumn{3}{|c|}{ Secured Debt Covers $<50 \%$ of Assets } \\
\hline Before & 0.55 & \\
\hline At Filing & 0.39 & 0.49 \\
\hline \multicolumn{3}{|c|}{ Secured Debt Covers $>50 \%$ but $<100 \%$ of Assets } \\
\hline Before & 0.08 & \\
\hline At Filing & 0.28 & 0.25 \\
\hline \multicolumn{3}{|c|}{ Secured Debt Covers $>100 \%$ of Assets } \\
\hline Before & 0.02 & \\
\hline At Filing & 0.22 & 0.16 \\
\hline
\end{tabular}

Note on sample sizes: Before: $n=97$; At Filing: $n=89$ for Total Secured Debt, $n=88$ for Secured Debt Held by Largest Creditor 
second column of Table 2 does, the claim held by the largest (or dominant) secured creditor to the value of the firm's assets.

Table 3 presents information about the bankruptcy process. Ninety-five percent of the cases were filed voluntarily by the debtors' owners. All but 3 percent of the cases were filed under Chapter $11 .{ }^{11}$ Among these cases, nearly 75 percent resulted in a confirmed plan of reorganization; most of the remaining cases resulted in dismissal or conversion to Chapter 7. We do not have direct indicators of whether a plan was prepackaged, so we assume that a case was prepackaged if confirmation occurred within four months. ${ }^{12}$ Eight percent of the Chapter 11 cases satisfied this criterion.

The fourth panel of Table 3 illustrates the frequency with which Chapter 11 cases resulted in the sale or liquidation of the business. A traditional reorganization -in which the distressed firm's creditors retain stakes in the firm and, often, become its new owners-occurred in only 32 percent of the cases.

The final panel of Table 3 summarizes case duration. Across all Chapter 11 cases, the median duration to confirmation, dismissal, or conversion to Chapter 7 swas about 13 months. This figure is somewhat misleading, however, because many plans are liquidating plans that distribute the proceeds from a going-concern sale that occurred months before. In these cases, the fate of the firm (whether it would be reorganized or sold off) was decided long before a plan was confirmed. The final panel of Table 3 illustrates this phenomenon. Although we do not have the dates on which sales occurred, we do have the dates when motions to conduct a sale were filed. Among firms that were sold off, a motion to sell the firm was typically filed within the first two to three months of the case.

\section{SIMPLE MEASURES OF CREDITOR CONTROL AND CONFLICT}

\section{Creditor Control}

We can measure creditor control directly and indirectly. Direct measures include deviations from APR that favor equity holders and the terms of postpetition DIP financing. An indirect measure is the frequency of management turnover immediately before and after the bankruptcy filing. When a firm is

11 Bernstein $(2006,2$ n.3) reports the same percentage of involuntary filings in a study of Chapter 11 filings during 2001 by publicly traded corporations.

12 This cut-off captures all but two of the cases identified as "prenegotiated" in LoPucki's WebBRD database. The two exceptions were cases with durations of 6.9 and 8.7 months, respectively. 
Table 3. Filings and Outcomes

\begin{tabular}{|c|c|c|c|c|c|}
\hline Variable & Mean & SD & Median & Min & Max \\
\hline \multicolumn{6}{|l|}{ Types of Filings $(n=153)$} \\
\hline Chapter 7 Filing & 0.03 & & & & \\
\hline Chapter 11 Filing & 0.97 & & & & \\
\hline Prepackaged Chapter 11 Filing & 0.08 & & & & \\
\hline Involuntary Filing & 0.05 & & & & \\
\hline \multicolumn{6}{|l|}{ Venue $(n=153)$} \\
\hline Filed in Delaware & 0.22 & & & & \\
\hline Filed in SDNY & 0.10 & & & & \\
\hline \multicolumn{6}{|l|}{ Legal Outcomes in Chapter $11(n=149)$} \\
\hline Confirmed Chapter 11 & 0.75 & & & & \\
\hline Chapter 11 Converted to Chapter 7 & 0.13 & & & & \\
\hline Chapter 11 Dismissed & 0.09 & & & & \\
\hline Case Ongoing & 0.03 & & & & \\
\hline \multicolumn{6}{|l|}{ Economic Outcomes in Chapter 11} \\
\hline Traditional Reorganization $(n=148)$ & 0.32 & & & & \\
\hline Entire Firm Sold Off $(n=148)$ & 0.66 & & & & \\
\hline Any Asset Sales $(n=149)$ & 0.85 & & & & \\
\hline \multicolumn{6}{|l|}{ Case Duration in Chapter 11} \\
\hline To Legal Outcome $(n=145)$ & 15.63 & 11.91 & 13.10 & 1.13 & 74.30 \\
\hline To Motion for Sale of Firm $(n=25)$ & 2.87 & 3.92 & 0.90 & 0.00 & 16.20 \\
\hline To Motion for First Sale $(n=106)$ & 2.26 & 3.07 & 1.33 & 0.00 & 16.57 \\
\hline
\end{tabular}

distressed, its creditors influence the choice of management. DIP loan covenants, for example, routinely include provisions forbidding the debtor from replacing a newly appointed CEO ${ }^{13}$ To be sure, management turnover might be caused by dynamics wholly separate from creditor control. Shareholders of a troubled firm might replace the CEO because they hope new leadership will help the firm recover (or because they hope to avoid creditor control, which might result if the firm becomes further distressed). We view management turnover as an important, but not decisive, indicator of creditor control. We

13 Chatterjee, Dhillon, and Ramirez $(2004,3107)$ report that 95 percent of DIP loans contain covenants forbidding changes in management, control, and ownership. 
expect creditor control to be positively correlated with CEO turnover, but we cannot rule out other causes of high turnover.

Statistics on CEO turnover appear in Table 4. We computed turnover rates by comparing the name of the CEO on the date of the bankruptcy filing (as reported in PALER documents) to the name of the CEO reported in Compustat data for the two year period preceding the bankruptcy filing. Table 4 shows that 70 percent of CEOs were replaced within the two years preceding the bankruptcy filing. This turnover rate is markedly higher than the 45 percent rate observed by Kaplan and Minton (2006) among Fortune 500 firms during a comparable two-year period (1999-2000). ${ }^{14}$ It is also significantly higher than the 55 percent rate observed by Gilson (1989) among firms that entered bankruptcy during the 1980s. The frequency of turnover in our data rises further, to about 80 percent, when we include CEO replacements that occurred during the two years after the case commenced (as reported in PACER documents). This is undoubtedly an underestimate, however, because we did not look systematically for post-petition turnover. If CEO turnover is a good proxy for creditor control, these data point to pervasive control. At a minimum, it strongly suggests that managers are not able to use Chapter 11 as a safe harbor when their firms encounter financial distress.

Direct measures of creditor control appear in Tables 5 and 6. Table 5 shows that deviations from APR_payments to shareholders when creditors have not been paid in full-were rare, occurring in only 9 percent of all Chapter 11 cases (reorganizations, dismissals, and conversions to Chapter 7) and in 12 percent of confirmed plans of reorganization. This is a dramatic shift from the frequency of APR violations during the 1980s. In a study of publicly traded corporations that entered Chapter 11 between 1979 and 1986, for example, Weiss (1990) found APR violations in 78 percent of the cases. He also found that equity holders received some payment in 80 percent of the cases. That was true in only 18 percent of confirmed plans of reorganization in our sample. If APR deviations measure the degree of control exercised by managers and equity holders, as is commonly thought, the patterns in Table 5 show that these groups exercise little influence over the modern Chapter 11 process. The patterns point instead to pervasive creditor control.

Table 6 documents the frequency and terms of pre- and post-petition financing. Prior to entering bankruptcy, 75 percent of the businesses

14 The 45 percent figure was computed based on Table 2 of Kaplan and Minton (2006). The average number of firms during 1999 and 2000 was 733; the total number of CEO turnovers was 328 , which is about 45 percent of 733 . 
Table 4. CEO Turnover

\begin{tabular}{|c|c|}
\hline Variable $(\boldsymbol{n}=\mathbf{1 3 6})$ & Proportion \\
\hline Turnover within one year preceding the bankruptcy filing & 0.40 \\
\hline Turnover within two years preceding the bankruptcy filing & 0.70 \\
\hline
\end{tabular}

Table 5. Equity Payoffs

\begin{tabular}{|l|c|c|}
\hline \multicolumn{1}{|c|}{ Variable } & Obs. & Proportion \\
\hline Equity holders Received Payment & & \\
\hline All cases & 115 & 0.13 \\
\hline Confirmed Chapter 11 plans & 82 & 0.18 \\
\hline APR Deviation & & \\
\hline All cases & 115 & 0.09 \\
\hline Confirmed Chapter 11 plans & 82 & 0.12 \\
\hline
\end{tabular}

obtained financing through a revolving pre-petition credit facility (PCF). In 97 percent of these cases, the facilities were secured by all or nearly all of the firm's assets. Recall that we observe remarkably low levels of secured debt among the firms in our sample when we study documents filed one or two years before their bankruptcy filings. It seems likely, then, that most PCFs originated during the year before the bankruptcies. This is a strong measure of senior creditor control. If all of a firm's assets are encumbered by liens, it cannot obtain additional secured financing in bankruptcy without obtaining permission from or offering adequate protection to the prepetition secured lender (11 U.S.C. $\$ \$ 364(\mathrm{c})$, (d)).

Upon entering bankruptcy, 50 percent of the firms obtained post-petition DIP financing. Another 26 percent obtained liquidity by filing motions to use cash collateral (that is, cash in which a creditor has a security interest). These motions differ little from those for DIP financing; in either case, the debtor hopes to finance its operations using funds over which a lender has control. Indeed, cash collateral motions frequently contain the same terms found in motions for DIP financing. In 76 percent of the cases, the firm obtained financing through a DIP loan or an order permitting it to use cash collateral. This, in turn, suggests that the providers of the firms' credit lines have substantial control over, at a minimum, the timing of the bankruptcy filings. These results are important because they provide confirmation that a primary justification for the bankruptcy filing is the debtor's need to access cash that is unavailable outside bankruptcy. 
Table 6. Terms of Financing

\begin{tabular}{|c|c|c|c|c|c|c|}
\hline & Obs. & Mean & SD & Median & Min & Max \\
\hline \multicolumn{7}{|l|}{ Pre-petition Financing } \\
\hline \multicolumn{7}{|l|}{ All Firms } \\
\hline Had Pre-petition Credit Facility (PCF) & 107 & 0.75 & & & & \\
\hline \multicolumn{7}{|l|}{ Firms with PCF } \\
\hline PCF is secured & 77 & 0.97 & & & & \\
\hline PCF is Secured By All Assets & 77 & 0.78 & & & & \\
\hline \multicolumn{7}{|l|}{ Post-petition DIP Financing } \\
\hline \multicolumn{7}{|l|}{ All Firms } \\
\hline Had DIP Loan & 153 & 0.50 & & & & \\
\hline Used Cash Collateral & 153 & 0.26 & & & & \\
\hline Used DIP Loan or Cash Collateral & 153 & 0.76 & & & & \\
\hline \multicolumn{7}{|l|}{ Firms with DIP Loan } \\
\hline DIP Lender is also PCF Lender & 63 & 0.54 & & & & \\
\hline \multicolumn{7}{|l|}{ Size of DIP Loan } \\
\hline Maximum DIP Loan, $\$$ millions & 66 & 93.42 & 249.82 & 20.00 & 0.20 & $1,743.00$ \\
\hline DIP Loan $\div$ Assets & 51 & 0.89 & 3.70 & 0.15 & 0.01 & 26.28 \\
\hline DIP Loan $\div$ Unencumbered Assets & 51 & -0.72 & 12.14 & 0.15 & -82.55 & 17.23 \\
\hline \multicolumn{7}{|l|}{ Priority of DIP Loan } \\
\hline \multicolumn{7}{|l|}{ Firms with DIP Loan } \\
\hline DIP Secured by All Assets? & 62 & 0.92 & & & & \\
\hline DIP with Priming Security Interest? & 62 & 0.65 & & & & \\
\hline DIP with Admin. Expense Superpriority? & 63 & 0.95 & & & & \\
\hline \multicolumn{7}{|l|}{ Firms with Priming Security Interest } \\
\hline DIP Lender is also PCF Lender & 40 & 0.80 & & & & \\
\hline \multicolumn{7}{|l|}{ Financial covenants in DIP Loan } \\
\hline Budget Limits & 60 & 0.72 & & & & \\
\hline Capital Expenditure Limits & 60 & 0.50 & & & & \\
\hline EBITDA Targets & 60 & 0.42 & & & & \\
\hline Any Financial Covenants & 60 & 0.90 & & & & \\
\hline \multicolumn{7}{|l|}{ Other Covenants in DIP Loan } \\
\hline Automatic Stay Terminates in Event of Default & 60 & 0.85 & & & & \\
\hline Power of Attorney & 60 & 0.20 & & & & \\
\hline Deadlines for Disclosure Statement or Plan & 60 & 0.18 & & & & \\
\hline Sale Requirements & 63 & 0.17 & & & & \\
\hline
\end{tabular}


The final three panels of Table 6 dissect the terms of DIP loans. 95 percent of the loans give the lender administrative expense superpriority. This is a potent form of control because it gives the lender the right to demand repayment in cash before any plan of reorganization can be confirmed. Ninety-two percent of the loans give the lender a security interest in all of the firm's assets. This too is an important mechanism of control when combined with covenants permitting the lender to seize collateral-without petitioning for court authorization-in the event of default. These covenants are present in 85 percent of DIP loans, as shown in the final panel of Table 6.

Other covenants enhance creditor control. Perhaps our most surprising result, and the strongest evidence of senior creditor control, is the large percentage of loans that impose specific line-item budgets on the firm (72 percent of loans). These budgets obligate the firm to submit detailed evidence of cash receipts and expenditures. A default occurs if the firm deviates from any given line-item by a significant margin (usually 5 to 15 percent). Other covenants are of the more standard variety and restrict capital expenditures (50 percent) or require the firm to achieve certain profitability or EBITDA targets (42 percent). Ninety percent of the loans contained at least one of these provisions, as shown in the fifth panel of Table 6.

The fourth panel of Table 6 also shows that 65 percent of DIP loans contain provisions giving the lender a priming lien, that is, a security interest with priority over pre-existing security interests. This phenomenon could be seen as a means by which DIP lenders divert value from pre-existing secured lenders. Most DIP lenders, however, are the same banks that extended PCFs to the debtor. A priming lien typically primes only the DIP lender's own pre-existing security interest. There is no diversion of value. As Table 6 illustrates, 80 percent of priming liens involve the DIP lender priming itself; in the remaining 20 percent, the DIP lender obtained a priming lien at the expense of another secured lender. In these calculations, we look only at the names of the lead lenders. If the loans were syndicated, we do not know the degree of overlap in syndicate membership between the PCF and DIP loans. We also cannot say whether a DIP lender adequately compensated a pre-existing secured lender for a priming lien.

Senior creditor control, then, appears to be pervasive in a large number of corporate bankruptcies. The majority of firms see their CEOs replaced, and they sign loan agreements that give lenders significant control over the course of the Chapter 11 process. Evidence from PCFs indicates that, for most firms, the senior lender has effective control over the debtor's access to 
cash and thus determines the timing of the bankruptcy filing. Our analysis of DIP covenants suggests that this control extends beyond the filing and continues throughout the bankruptcy case in the form of line-item budgetary control over the debtor's operations.

\section{Creditor Conflict}

Tables 7 and 8 offer direct and indirect measures of creditor conflict. Table 7 focuses on an indirect measure-creditor concentration. When most secured debt is held by one party and most unsecured debt by another, creditor conflict is likely to be significant. Although not reported in Table 7, secured debt is highly concentrated. ${ }^{15}$ In the median firm, the top three secured creditors hold 100 percent of secured debt (if the debt was syndicated, we count the group as a single creditor). Table 7 shows that unsecured claims are somewhat more dispersed, but still significantly concentrated. In the median firm, over 50 percent of the unsecured debt is held by three creditors.

Direct measures of creditor conflict are presented in Table 8, which catalogues the frequency with which the unsecured creditors' committee (UCC) and the senior lender (the PCF lender or DIP lender) objected to actions proposed by the debtor corporation. With respect to the UCC, the most common objection (in 46 percent of cases in which a UCC was organized) was to the appointment or compensation of professionals, whose fees reduce returns to unsecured creditors. Objections to the DIP loan (40 percent) and to asset sales (37 percent) were the next most common. These UCC objections suggest strongly that, in a large number of cases, the managers of the corporation are not acting to maximize the returns of unsecured creditors, who are often the firms' residual claimants.

Although senior creditors obtain substantial control through their loan agreements, they too might object to actions proposed by the debtor corporation. The most common objections are to the appointment or compensation of professionals ( 25 percent), asset sales (13 percent), and the use of cash collateral (11 percent). The frequency of objections raises doubts again about the conduct of management. In a significant number of cases, managers appear not to be acting to further the interests of either senior or junior lenders. We see, then, creditor conflict as well as manager-creditor conflict.

15 We measure creditor concentration using data from the parent company only. It was prohibitively complex to assess creditor concentration at both the parent and subsidiaries due to inter-company claims. 
Table 7. Unsecured Creditor and Equity Concentration

\begin{tabular}{|l|l|}
\hline & Proportion \\
\hline Unsecured Debt Concentration ( $\boldsymbol{n}=\mathbf{8 8}$ ) & 0.39 \\
\hline Largest Creditor, Share of Unsecured Parent Debt & 0.54 \\
\hline Top 3 Creditors, Share of Unsecured Parent Debt & \\
\hline Equity Concentration ( $\boldsymbol{n}=102)$ & 0.36 \\
\hline Largest Shareholder, Share of Equity & 0.48 \\
\hline Top 2 Shareholders, Share of Equity & 0.05 \\
\hline Equity Committee Appointed $(n=153)$ & \\
\hline
\end{tabular}

Table 8. Objections and Motions

\begin{tabular}{|l|l|l|l|l|l|l|}
\hline \multicolumn{2}{|c|}{ Variable } & Mean & SD & Median & Min & Max \\
\hline Unsecured Creditors Committee (n=112) & 0.71 & & & & \\
\hline Any Objections & 0.46 & & & & \\
\hline Objected to Professionals & 0.40 & & & & \\
\hline Objected to DIP Loan & 0.37 & & & & \\
\hline Objected to Sale & 0.21 & & & & \\
\hline Objected to Exclusivity Extension & 0.20 & & & & \\
\hline Objected to Plan & 0.07 & & & & \\
\hline Objected to Lifting Stay & 0.04 & & & & \\
\hline Moved for Exclusivity Extension & 0.04 & & & & \\
\hline Objected to Conversion & 0.04 & & & & \\
\hline Moved for Conversion & 0.01 & & & & \\
\hline Moved for Sale & 1.83 & 1.51 & 2.00 & 0.00 & 5.00 \\
\hline Total Objections & & & & & \\
\hline DIP Lender or PCF Lender ( $\boldsymbol{n}=107$ ) & 0.46 & & & & \\
\hline Any Objections & 0.25 & & & & \\
\hline DIP/PCF Lender Objected to Professionals & 0.13 & & & & \\
\hline DIP/PCF Lender Objected to Sale & 0.09 & & & & \\
\hline DIP/PCF Lender Objected to Cash Collateral Use & 0.11 & & & & \\
\hline DIP/PCF Moved for Lifting Stay & 0.03 & & & & \\
\hline DIP/PCF Lender Objected to Exclusivity Extension & 0.07 & & & & \\
\hline DIP/PCF Lender Objected to Plan & 0.07 & & & & \\
\hline DIP/PCF Lender Objected to Lifting Stay & 0.05 & & & & \\
\hline DIP/PCF Lender Moved for Conversion & 0.03 & & \\
\hline
\end{tabular}


Table 8. Continued

\begin{tabular}{|l|c|c|c|c|c|}
\hline \multicolumn{1}{|c|}{ Variable } & Mean & SD & Median & Min & Max \\
\hline DIP/PCF Lender Objected to Conversion & 0.02 & & & & \\
\hline Total DIP/PCF Objections & 0.82 & 1.10 & 0.00 & 0.00 & 4.00 \\
\hline
\end{tabular}

Note: Statistics for the first panel are based on the subsample of cases in which an unsecured creditors' committee (UCC) was formed; statistics for second panel are based on the subsample in which there was a DIP or PCF lender.

\section{HYPOTHESIS TESTS}

In this section, we outline-and then test-a simple theory of creditor conflict and its effects on a particular bankruptcy outcome: the decision to reorganize or sell a firm.

\section{Theory}

Our primary question is whether (and to what extent) creditor conflict affects the ultimate allocation of the bankrupt firm's assets. This question is important because creditor control and conflict can lead to suboptimal sales or reorganizations. ${ }^{16}$ We provide a formal model of creditor conflict and its effect on bankruptcy outcomes in Appendix A. An intuitive sketch of the model is provided below. ${ }^{17}$

First consider the incentives of a secured lender whose claim is oversecured, meaning that the firm's assets, if sold immediately, would yield more than the lender's claim. This implies that the lender is paid in full, even if the sale occurs at a "fire sale" price that could be avoided by waiting and perhaps reorganizing. Relative to a strategy that maximizes the value of the bankruptcy estate, the oversecured lender is always biased toward an immediate resolution of the case. If asset value is volatile, the delay caused by the reorganization process only harms the lender. Any increase in value offers no benefit because the lender's payoff is capped by its claim. Decrease in value can be costly, possibly reducing the lender's payoff.

Although the oversecured creditor always prefers an immediate sale, its ability to realize its preferred outcome should depend on the extent to

16 LoPucki and Doherty (2007), for example, argue that bankruptcy sales generate significantly less value for creditors than traditional reorganizations.

17 Franks and Sussman (2005) develop a similar theory and test it using data on relatively small, distressed companies in the United Kingdom, where senior creditors have much stronger control over the bankruptcy process than in the United States. Their empirical analysis yields results that are consistent with the theory but are not statistically significant. 
which it is oversecured. When a creditor is substantially oversecured, the bankruptcy judge is unlikely to grant requests for an immediate sale. When the value of the firm greatly exceeds the secured creditor's claim, it is probable that the creditor will be paid in full, even in a reorganization. As the secured creditor becomes only slightly oversecured, we expect that the judge is more likely to approve attempts by the secured creditor to move for a quick sale, because its claim is at greater risk.

Now consider a secured lender whose claim is undersecured, that is, its claim exceeds the sale value of the firm's assets. In this case, the secured lender is not paid in full in a sale. If the creditor is slightly undersecured, its incentives are similar to those of the slightly oversecured creditor. Reorganization can increase its payoff only slightly, but a decline in firm value can hurt its payoff significantly. As the secured creditor becomes substantially undersecured, its interests are better aligned with maximizing the value of the estate because it captures nearly all the upside from a successful reorganization. The substantially undersecured creditor is the firm's approximate residual claimant and entitled to the entire value of the firm. ${ }^{18}$ Thus, if an illiquidity problem makes reorganization socially optimal, the lender prefers to reorganize the firm to improve its payoff.

Finally, consider unsecured creditors. They generally exhibit a bias toward lengthy cases, especially reorganizations, when the firm enters bankruptcy with senior secured debt. Longer delay adds to the risk of their eventual payoff, and junior claimants typically exhibit a preference toward greater risk. ${ }^{19}$ When the firm has no secured debt, however, unsecured creditors prefer to make the reorganization-versus-sale decision in a way that is consistent with the maximization of firm value.

This simple analysis of creditor conflict predicts that a bankrupt firm's creditors will make the value-maximizing decision when secured creditors are substantially undersecured or when there is no secured debt. ${ }^{20}$ If the

18 The undersecured creditors' incentives are not exactly consistent with social efficiency. The creditors still have a slight bias toward a quick sale, all else equal, because unsecured creditors might capture some of the upside risk to a high-value reorganization.

19 Here, we are employing standard logic that is normally used to describe equity-versus-debt conflicts. Unsecured creditors expect to share most of the gains from a successful (high value) reorganization, but they expect to avoid most of the losses from a low-value reorganization or liquidation. These losses are borne primarily by senior secured creditors. Due to this asymmetry in payoffs, unsecured creditors prefer risk, all else equal (Jensen and Meckling 1976).

20 A few important assumptions are implicit in this argument. For instance, it assumes that secured creditors have full control when they are oversecured. It also assumes that equity will be extinguished with certainty (which is approximately true in our data). 
capital structure is a mix of oversecured and unsecured debt, a bias toward sale will result. The intensity of the bias depends on which party exerts more control over the outcome. We expect that senior creditors will have greater influence over the outcome when their claims are large relative to the value of the firm. Thus, a capital structure with slightly oversecured senior creditors will produce relatively quick cases and yield sales more often than traditional reorganizations. As the power of unsecured creditors increases relative to secured creditors, the reverse should be true.

These observations point to the following hypothesis: Because time to resolution is generally longer when a firm is reorganized than when it is sold off, a traditional reorganization is more likely among (a) firms with no secured debt and those with undersecured lenders than among (b) firms with oversecured lenders.

This hypothesis would be easy to test if capital structures were randomly assigned to firms before they entered bankruptcy. With random assignment, we could assume that any correlation between the probability of reorganization and secured debt levels is due to dynamics during the bankruptcy case, such as conflict between secured lenders and other participants in the bankruptcy process. In reality, firms select their capital structures. It is possible that the reasons for choosing different secured debt ratios are the same reasons driving firms' preferences over traditional reorganizations and going-concern sales. This is an important issue because most secured debt is incurred within the year or two preceding the bankruptcy filing. There could be a close relationship between a firm's expectations in bankruptcy and its decisions to take on secured debt.

Asset liquidity is one factor that could drive both a firm's decision to take on secured debt before bankruptcy and its preference for traditional reorganization in bankruptcy. The more liquid a firm's assets-due to tangibility or industry conditions (Almeida and Campello 2007)—the more likely it is to take on secured debt. ${ }^{21}$ At the same time, a firm with liquid assets is less likely to suffer the kinds of problems (such as asymmetric information) that make a traditional reorganization attractive, as Pulvino (1998) has shown. Asset liquidity, then, explains both capital structure and bankruptcy outcomes. Firms with relatively liquid assets are predicted to have both high secured debt ratios and low probabilities of reorganization. The

21 Sibilkov (2007) offers recent evidence showing a positive correlation between asset liquidity and secured indebtedness. 
opposite is expected among firms with relatively illiquid assets: These firms will have low secured debt ratios and high probabilities of reorganization.

Thus, a theory based on asset liquidity predicts a monotonic relationship between secured indebtedness and the probability of traditional reorganization. Our theory-based on the divergent preferences of unsecured, undersecured, and oversecured creditors-implies a non-monotonic relationship. The probability should be higher when the ratio of secured debt to assets is near zero and when it is much larger than one; the probability should be lower when the ratio is in between. This non-monotonic pattern distinguishes our theory from the pattern predicted by an asset liquidity theory.

\section{Simple Statistics}

Table 9 presents data on capital structure and bankruptcy outcomes at different levels of the secured debt-to-assets ratio: unsecured firms (0), highly oversecured firms (0-0.50), moderately oversecured firms (0.50-1.0), and undersecured firms $(>1.0)$.

Table 9. Firm Characteristics by Secured Debt Level

\begin{tabular}{|c|c|c|c|c|}
\hline & \multicolumn{4}{|c|}{ Secured Debt/Assets } \\
\hline & $\begin{array}{c}0 \\
\text { Unsecured } \\
(N=9)\end{array}$ & $\begin{array}{c}0-0.50 \\
\text { Highly } \\
\text { Oversecured } \\
(\mathrm{N}=35)\end{array}$ & $\begin{array}{c}0.50-1.0 \\
\text { Moderately } \\
\text { Oversecured } \\
(\mathrm{N}=25)\end{array}$ & $\begin{array}{c}>1.0 \\
\text { Undersecured } \\
(\mathrm{N}=20)\end{array}$ \\
\hline Traditional reorganization & 0.44 & 0.34 & 0.21 & 0.47 \\
\hline UCC objected to sale & 0.11 & 0.29 & 0.48 & 0.20 \\
\hline $\begin{array}{l}\text { UCC objected to sale, } \\
\text { conditional on sale }\end{array}$ & 0.20 & 0.41 & 0.55 & 0.33 \\
\hline CEO turnover, 2 years & 0.67 & 0.81 & 0.72 & 0.70 \\
\hline Public & 0.67 & 0.74 & 0.80 & 0.95 \\
\hline Prepack & 0.11 & 0.09 & 0.04 & 0.05 \\
\hline \multirow[t]{2}{*}{ Assets, mean (median) } & 28.19 & $1,093.16$ & 187.84 & 105.95 \\
\hline & $(4.34)$ & (195.52) & $(97.92)$ & $(18.56)$ \\
\hline \multirow[t]{2}{*}{$\begin{array}{l}\text { Compustat assets, mean } \\
\text { (median) }\end{array}$} & 79.20 & $1,795.15$ & 463.07 & 610.15 \\
\hline & $(18.86)$ & $(668.67)$ & $(158.29)$ & $(151.2)$ \\
\hline \multirow[t]{2}{*}{ Sec. Debt, mean (median) } & 0.00 & 238.46 & 153.85 & 238.69 \\
\hline & $(0.00)$ & (32.31) & (87.73) & $(70.87)$ \\
\hline
\end{tabular}


Several distinctive patterns emerge. First, unsecured and undersecured firms are much smaller than oversecured firms. For example, the median unsecured and undersecured firms had assets worth $\$ 4.34$ million and $\$ 18.56$ million, respectively. By contrast, the median oversecured firm had assets ranging from $\$ 97.92$ million (moderely oversecured) to $\$ 195.52$ million (highly oversecured). The small size of undersecured firms is somewhat deceiving, however. Prior to entering bankruptcy, these firms were comparable in size to slightly oversecured firms (for whom secured debt exceeded 50 percent of asset value). During the months prior to filing, undersecured firms suffered a larger decrease in value than any other type of firm. We are unsure why the decline was so steep for these firms.

We see a different relationship between secured debt levels and secured debt ratios. Focusing on medians, undersecured firms had about as much secured debt ( $\$ 70.87$ million) as moderately oversecured firms $(\$ 87.29$ million), even though the undersecured firm had much smaller asset value. Thus, variation in secured debt ratios appears to be due more to variation in asset value than in the level of secured debt. This highlights the importance of controlling for asset value in the multivariate analysis below.

The most important pattern in Table 9, for our purposes, is the relationship between the probability of reorganization and the ratio of secured debt to assets. We see the hypothesized non-monotonic relationship. The likelihood of traditional reorganization is higher among unsecured (44 percent) and undersecured firms ( 47 percent) than it is among moderately oversecured (21 percent) and highly oversecured firms (34 percent).$^{22}$ Also consistent with our theory, the probability of reorganization among oversecured firms is declining in the ratio of secured debt to assets, but the difference is not statistically significant.

Figure 1 illustrates this non-monotonic relationship using locally weighted scatterplot smoothing. ${ }^{23}$ Here, a lowess curve displays the relationship between (a) the probability of reorganization, displayed on the y-axis, and (b) the ratio of secured debt to assets, expressed in logs,

22 The difference between undersecured and moderately oversecured firms (50-100\%) is statistically significant at the 5 percent level using a one-tail test. The difference between unsecured and highly oversecured firms (0-50\%) is not significant, probably due to small sample size.

23 The curve in Figure 1 is implemented using Stata's default settings, including a bandwidth equal to 0.8 . An intuitive description of the lowess procedure is available in Imbs and Wacziarg (2003, 67-68). 
Figure 1. Lowess curve relating the probability of reorganization (y-axis) to the ratio of secured debt to assets, in logs (x-axis).

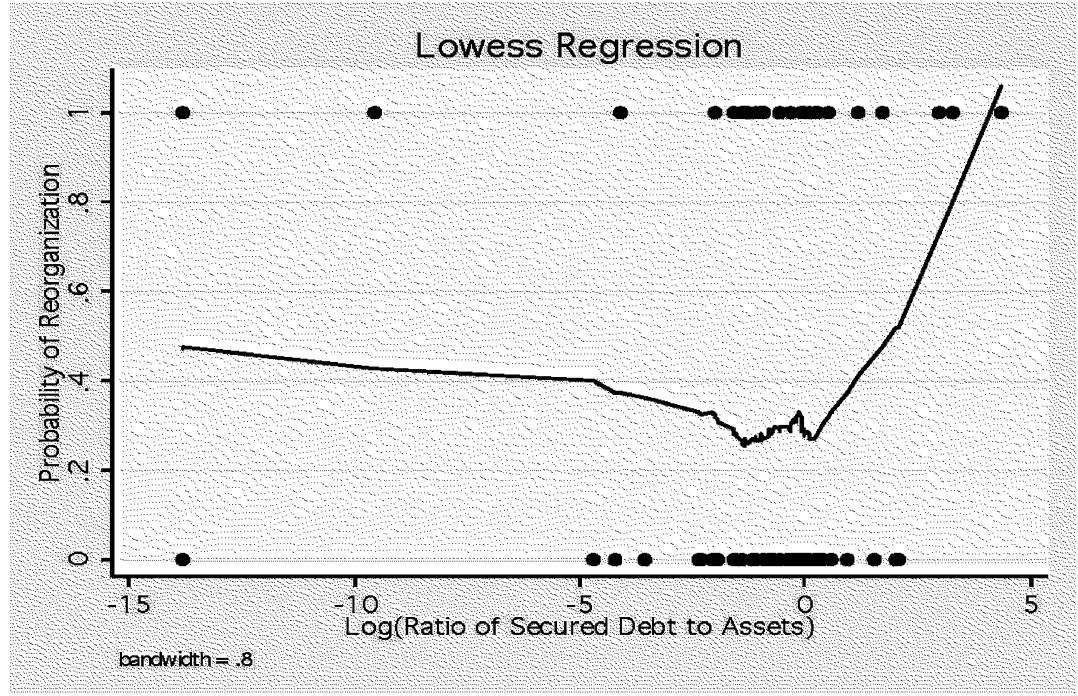

displayed on the $\mathrm{x}$-axis. The lowess curve is a standard procedure for drawing smooth curves through scatter plots. For each observation of the secured debt-to-assets ratio $\left(x_{i}\right)$, the probability of reorganization $(y)$ is regressed on a small number of observations surrounding $x_{i}$. The fitted values from these local regressions are connected to form the lowess curve depicted in Figure 1. This procedure is attractive because it allows the relationship between the probability of reorganization $(y)$ and the secured debt-to-assets ratio $(x)$ to vary across different values of the ratio. The lowess curve in Figure 1 displays a distinct non-monotonic relationship. Among oversecured firms, the probability of reorganization is gradually decreasing in the secured debt-to-assets ratio; among undersecured firms, it is sharply increasing in the ratio.

These patterns are consistent with the hypothesis that secured lender preferences distort real economic outcomes. But if secured lenders can distort economic outcomes, we should see a response from the UCC when lenders propose outcomes that will reduce payoffs to unsecured creditors. Objections to sales, for example, should be more common in cases involving oversecured firms than in those involving unsecured or undersecured firms. Objections should be less common among unsecured firms 
because unsecured creditors should have significant influence over the bankruptcy process when no secured creditors exist. Objections should be less common among undersecured firms for two reasons. First, undersecured lenders are less likely to agitate for a quick sale. Second, when these lenders do agitate for a sale, a court is unlikely to grant a UCC's objection (relative to a case where the lenders are oversecured). This is because undersecured lenders are effectively the firm's residual claimants and will tend to advocate the socially efficient bankruptcy outcome. Because it is not costless to file an objection (a lawyer must be hired and documents drafted) and because any objection is likely to be denied, we expect UCC objections to be less common in undersecured firms than in oversecured firms.

These predictions are borne out in the data, as Table 9 shows. Objections to sale occurred in 29 to 48 percent of cases involving oversecured firms (the difference between highly and moderately oversecured firms is statistically significant at the 6 percent level, using a one-tail test).The percentages are much lower in cases involving unsecured and undersecured firms ( 11 percent and 20 percent, respectively). The difference between undersecured and moderately oversecured firms is significant at the 3 percent level, using a one-tail test; the difference between unsecured and highly oversecured firms is not significant, likely due to small sample size.

\section{Multivariate Analysis}

Tables 10 and 11 analyze the probability of traditional reorganization using a probit model. The dependent variable equals 1 when a Chapter 11 case concluded with a traditional reorganization and equals 0 when the case concluded in sale of the entire firm. The latter category includes liquidating plans of reorganization, section 363 sales, conversions to Chapter 7, and dismissals. The coefficients in Tables 10 and 11 are elasticities, that is, they report the change in the probability of reorganization associated with either a 1 percent change in the dependent variable (if it is continuous) or a discrete change in that variable (if it is a dummy).

Table 10 presents models in which the probability of traditional reorganization is a function of the pervasiveness of secured debt, firm size, and other variables. In Columns (1) through (4), the variable Secured Debt $=0$ is a dummy equal to one for unsecured firms and zero for all others. Similarly, the variable Secured Debt $>100 \%$ Assets is a dummy equal to one among 
Table 10. Probability of Traditional Reorganization Probit Model, Reporting Marginal Effects

\begin{tabular}{|c|c|c|c|c|c|c|}
\hline & (1) & (2) & (3) & (4) & (5) & (6) \\
\hline \multirow[t]{2}{*}{ Secured Debt $=0$} & $0.367^{\star}$ & $0.355^{\star}$ & $0.418^{\star}$ & $0.445^{\star \star}$ & & \\
\hline & {$[0.072]$} & {$[0.082]$} & {$[0.052]$} & {$[0.039]$} & & \\
\hline \multirow[t]{2}{*}{ Secured Debt $>0 \%$ but $<50 \%$ Assets } & & & & & -0.332 & $-0.362^{\star}$ \\
\hline & & & & & [0.121] & {$[0.082]$} \\
\hline \multirow[t]{2}{*}{ Secured $>50 \%$ but $<100 \%$ Assets } & & & & & $-0.352^{\star \star}$ & $-0.354^{\star \star}$ \\
\hline & & & & & {$[0.042]$} & {$[0.040]$} \\
\hline \multirow[t]{2}{*}{ Secured Debt $>100 \%$ Assets } & $0.380^{\star \star}$ & $0.388^{\star \star}$ & $0.416^{\star \star \star}$ & $0.455^{\star \star \star}$ & 0.004 & 0.016 \\
\hline & {$[0.012]$} & {$[0.012]$} & {$[0.008]$} & {$[0.009]$} & {$[0.985]$} & [0.937] \\
\hline \multirow[t]{2}{*}{ Assets (millions) } & $0.061^{\star \star}$ & $0.072^{\star \star}$ & $0.084^{\star \star}$ & $0.071^{\star}$ & $0.079^{\star \star}$ & 0.070 \\
\hline & {$[0.040]$} & {$[0.028]$} & {$[0.017]$} & {$[0.078]$} & {$[0.043]$} & {$[0.124]$} \\
\hline \multirow[t]{2}{*}{ Publicly Traded } & $-0.261^{\star}$ & $-0.265^{\star}$ & $-0.293^{\star \star}$ & $-0.277^{\star}$ & $-0.288^{\star}$ & $-0.275^{\star}$ \\
\hline & {$[0.062]$} & {$[0.052]$} & {$[0.048]$} & {$[0.058]$} & {$[0.058]$} & {$[0.062]$} \\
\hline \multirow[t]{2}{*}{ Telecom } & & 0.026 & -0.025 & -0.086 & -0.025 & -0.087 \\
\hline & & {$[0.887]$} & {$[0.903]$} & {$[0.663]$} & {$[0.903]$} & {$[0.661]$} \\
\hline \multirow[t]{2}{*}{ Software, Internet, High-Tech } & & 0.121 & 0.154 & 0.121 & 0.150 & 0.121 \\
\hline & & {$[0.430]$} & {$[0.350]$} & {$[0.454]$} & {$[0.363]$} & {$[0.455]$} \\
\hline \multirow[t]{2}{*}{ Finance } & & 0.019 & 0.131 & 0.257 & 0.107 & 0.250 \\
\hline & & {$[0.943]$} & {$[0.594]$} & {$[0.330]$} & {$[0.679]$} & {$[0.369]$} \\
\hline \multirow[t]{2}{*}{ Pre-petition CEO turnover } & & & $0.218^{\star}$ & $0.225^{\star \star}$ & $0.211^{\star}$ & $0.222^{\star \star}$ \\
\hline & & & {$[0.055]$} & {$[0.049]$} & {$[0.064]$} & {$[0.042]$} \\
\hline \multirow[t]{2}{*}{ Filed in Delaware } & & & -0.170 & -0.195 & -0.164 & -0.193 \\
\hline & & & [0.188] & [0.142] & {$[0.211]$} & [0.154] \\
\hline \multirow[t]{2}{*}{ Filed in SDNY } & & & -0.142 & -0.186 & -0.146 & -0.186 \\
\hline & & & {$[0.323]$} & {$[0.161]$} & {$[0.306]$} & [0.159] \\
\hline \multirow[t]{2}{*}{ Had DIP Loan } & & & & $0.217^{\star}$ & & $0.216^{\star}$ \\
\hline & & & & {$[0.079]$} & & {$[0.079]$} \\
\hline \multirow[t]{2}{*}{ UCC Objected to DIP Loan } & & & & -0.009 & & -0.005 \\
\hline & & & & {$[0.940]$} & & {$[0.969]$} \\
\hline \multirow[t]{2}{*}{ Equity Committee Appointed } & & & & -0.085 & & -0.083 \\
\hline & & & & {$[0.730]$} & & {$[0.739]$} \\
\hline Observations & 87 & 87 & 83 & 82 & 83 & 82 \\
\hline
\end{tabular}

Dependent variable equals 1 if the case resulted in a traditional reorganization and 0 if it resulted in a sale. Robust p-values appear in brackets. * indicates significance at the 10 percent level, ${ }^{\star \star}$ at the 5 percent level, and ${ }^{\star \star \star}$ at the 1 percent level. 
Table 11. Probability of Traditional Reorganization, Using Controls in Specification (2) of Table 10: Probit Model, Reporting Marginal Effects

\begin{tabular}{|c|c|c|}
\hline & (1) & (2) \\
\hline \multirow[t]{2}{*}{ Secured Debt $>0 \%$ but $<25 \%$ Assets } & $-0.353^{\star \star}$ & \\
\hline & [0.049] & \\
\hline \multirow[t]{2}{*}{ Secured Debt $>25 \%$ but $<50 \%$} & -0.133 & \\
\hline & {$[0.534]$} & \\
\hline \multirow[t]{2}{*}{ Secured Debt $>50 \%$ but $<75 \%$} & -0.259 & \\
\hline & {$[0.154]$} & \\
\hline \multirow[t]{2}{*}{ Secured Debt $>75 \%$ but $<100 \%$} & $-0.315^{\star}$ & \\
\hline & {$[0.060]$} & \\
\hline \multicolumn{3}{|l|}{ Secured Debt $>100 \%$} \\
\hline \multirow[t]{2}{*}{ Secured Debt $>0 \%$ but $<10 \%$} & & -0.254 \\
\hline & & {$[0.316]$} \\
\hline \multirow[t]{2}{*}{ Secured Debt $>10 \%$ but $<20 \%$} & & $-0.364^{\star \star}$ \\
\hline & & [0.049] \\
\hline \multirow[t]{2}{*}{ Secured Debt $>20 \%$ but $<30 \%$} & & -0.156 \\
\hline & & [0.536] \\
\hline \multirow[t]{2}{*}{ Secured Debt $>30 \%$ but $<40 \%$} & & -0.086 \\
\hline & & {$[0.757]$} \\
\hline \multirow[t]{2}{*}{ Secured Debt $>40 \%$ but $<50 \%$} & & -0.318 \\
\hline & & {$[0.167]$} \\
\hline \multirow[t]{2}{*}{ Secured Debt $>50 \%$ but $<60 \%$} & & -0.186 \\
\hline & & {$[0.456]$} \\
\hline \multicolumn{3}{|l|}{ Secured Debt $>60 \%$ but $<70 \%$} \\
\hline \multirow[t]{2}{*}{ Secured Debt $>70 \%$ but $<80 \%$} & & -0.309 \\
\hline & & {$[0.153]$} \\
\hline \multicolumn{3}{|l|}{ Secured Debt $>80 \%$ but $<90 \%$} \\
\hline \multirow[t]{2}{*}{ Secured Debt $>90 \%$ but $<100 \%$} & & -0.073 \\
\hline & & [0.774] \\
\hline \multirow[t]{2}{*}{ Secured Debt $>100 \%$} & 0.062 & 0.052 \\
\hline & {$[0.771]$} & [0.809] \\
\hline Observations & 87 & 78 \\
\hline
\end{tabular}

Dependent variable equals 1 if the case resulted in a traditional reorganization and 0 if it resulted in a sale. Robust p-values appear in brackets. * indicates significance at the 10 percent level, ${ }^{\star \star}$ at the 5 percent level, and ${ }^{\star \star \star}$ at the 1 percent level. 
undersecured firms and zero among all others. The coefficients for these variables tell us whether unsecured and undersecured firms are more (or less) likely to undergo a traditional reorganization than oversecured firms (the excluded category).

Column (1) displays a simple model in which reorganization is a function of only the pervasiveness of secured debt and the size of the firm, as measured by the log of total assets. Columns (2) through (4) expand this model to include covariates that are largely fixed at the moment a firm enters distress (Column (2)) and covariates that are endogenously determined as the firm becomes distressed and enters bankruptcy (Columns (3) and (4)). Regardless of the specification, the primary result is the same: The probability of a traditional reorganization is significantly higher (by 35 to 46 percentage points) among unsecured and undersecured firms. ${ }^{24}$ This is consistent with our theory linking secured creditor preferences and bankruptcy outcomes.

Columns (5) and (6) explore this theory further by distinguishing firms with no secured debt (the excluded category) from those with highly oversecured creditors (Secured Debt $>0 \%$ but $<50 \%$ Assets), moderately oversecured creditors (Secured Debt $>50 \%$ but $<100 \%$ Assets), and undersecured creditors (Secured Debt $>100 \%$ Assets). We do not distinguish between moderately and highly undersecured creditors because our data include too few undersecured firms. Our theory predicts that the probability of traditional reorganization will not differ between unsecured and undersecured firms. Among oversecured firms, the probability should be lower among firms with

24 Estimates in Table 10 are largely robust to sensitivity tests. The same or similar patterns are observed in models that exclude firms with asset values in the top and bottom 5 (or 10) percentile of the sample; winsorize the asset values of firms in the top and bottom 5 (or 10) percent of the sample; exclude firms with above-median assets; exclude firms with belowmedian assets; exclude prepackaged cases; and exclude financial firms. The results are less compelling when the sample is limited to publicly-traded firms. Although the probability of reorganization is significantly higher for undersecured than oversecured firms, there is no statistically significant difference between unsecured and oversecured firms. This may reflect the small sample size: there were only 6 publicly-traded, unsecured firms.

Another notable feature of Table 10 (and the robustness checks) is the overall significance of the models. The Wald test for these probits generally shows that the models are marginally significant overall. Although the model in column (1) of Table 10 is significant at the 6 percent level, the remaining models are significant at the $9,13,16,13$, and 16 percent levels, respectively. The marginal significance of these models is an artifact of the small sample size and the negative correlation between Assets and the Secured Debt dummies (in column (1), for example, the correlation between Assets and Secured Debt $=0$ and Secured Debt $>100 \%$ Assets is -0.28 and -0.38 , respectively). 
moderately oversecured debt than among those with highly oversecured debt. This theory finds some but not complete support. The probability of traditional reorganization does not differ between firms with no secured debt (the excluded category) and those with undersecured creditors, as predicted. But firms with highly oversecured debt are no more likely to reorganize than those with moderately oversecured debt.

Although this pattern is inconsistent with our theoretical model, it could be due to an arbitrary definition (based on a 50 percent cutoff) of moderately and highly oversecured debt. Table 11 explores this possibility. It uses a range of dummies to identify firms that are moderately and highly oversecured. Columns (1) and (2) report coefficients for the secured debt dummies only; coefficients for other covariates are suppressed. The estimates confirm an inconsistency with our theory-the probability of reorganization is not monotonically declining among oversecured firms as the ratio of secured debt to assets increases. This inconsistency might show that our theory is incomplete, or it might show that our dataset is too small to account for the heterogeneity among firms with oversecured debt.

Overall, however, Tables 10 and 11 are consistent with the hypothesis that bankruptcy outcomes are influenced by the divergent preferences of creditors. The results are also inconsistent with at least one alternative theory, based on asset liquidity. An argument based only on asset liquidity would predict that sale probabilities strictly increase as the ratio of secured debt to assets increases, but we find clear evidence of a non-monotonic relationship.

\section{DISCUSSION AND CONCLUSIONS}

The data presented here show that, among large privately and publicly held businesses, creditor control is pervasive. Equity holders and managers exercise little or no leverage during the reorganization process. 70 percent of CEOs are replaced within the two years preceding a bankruptcy filing. 66 percent of firms are sold off. Very few reorganization plans (at most 12 percent) deviate from the absolute priority rule to distribute value to equity holders.

Creditors dictate the dynamics of the reorganization process. Senior lenders exercise significant control through stringent covenants contained in DIP loans. Unsecured creditors gain leverage through objections and other court motions. 
Bargaining between secured and unsecured creditors can distort the reorganization process. A Chapter 11 case is significantly more likely to result in a sale if secured lenders are oversecured; it is less likely when these lenders are undersecured or when the firm has no secured debt at all.

We draw two conclusions from these patterns. First, the advent of creditor control has not eliminated the fundamental inefficiency of Chapter 11. Resource allocation questions (whether to sell or reorganize a firm) are confused with distributional questions (how much each creditor will receive). Instead of separating the two questions, Chapter 11 gives senior lenders, unsecured creditors, and equity holders leverage over resource allocation issues. The bargaining process can yield a misallocation of assets because these parties have distinct preferences. During the 1980s, this problem was noted by Baird and Jackson $(1984,121)$, who emphasized the conflict between creditors and equity holders. Today, as our data show, the problem persists, but now the conflict is between senior and junior lenders.

The second conclusions is that although creditors have obtained significant control over the reorganization process, it is somewhat unclear whether they have complete control. Both senior and junior lenders regularly object to actions taken by the debtor's management. This raises interesting questions about the incentives of managers. If equity holders are not part of the picture, and if both senior and junior creditors are unhappy with the firm's activities, in whose interest are the managers acting? 


\section{REFERENCES}

Acharya, Viral, Kose John, and Rangarajan Sundaram. 2005. Cross-Country Variations in Capital Structure: The Role of Bankruptcy Codes. Working paper.

Adler, Barry E. 1993. Financial and Political Theories of American Corporate Bankruptcy. Stan. L. Rev. 45:311-346.

Adler, Barry E., Vedran Capkun, and Lawrence A. Weiss. 2008. Destruction of Value in the New Era of Chapter 11. Working paper.

Almeida, Heitor and Murillo Campello. 2007. Financial Constraints, Asset Tangibility, and Corporate Investment. Rev. Fin. Stud. 20:1429-1460.

Baird, Douglas G. and Thomas H. Jackson. 1984. Corporate Reorganizations and the Treatment of Diverse Ownership Interests: A Comment on Adequate Protection of Secured Creditors in Bankruptcy. U. Chi. L. Rev. 51:97-130.

Baird, Douglas G. and Robert K. Rasmussen. 2002. The End of Bankruptcy. Stan. L. Rev. 55:751-789.

- 2003. Chapter 11 at Twilight. Stan. L. Rev. 56:673-699.

2006. Private Debt and the Missing Lever of Corporate Governance. U. Penn. L. Rev. 154:1209-1251.

Bebchuk, Lucian Arye, and Howard F. Chang. Bargaining and the Division of Value in Corporate Reorganizations. J. L. Econ. \& Org. 8:253-279.

Bernstein, Ethan S. 2006. All's Fair in Love, War \& Bankruptcy? Corporate Governance Implications of CEO Turnover in Financial Distress. Stan. J. L. Bus. \& Fin. 11:298-324.

Betker, Brian L. 1995. Management's Incentives, Equity's Bargaining Power, and Deviations from Absolute Priority in Chapter 11 Bankruptcies. J. Bus. 68:161-183.

Bharath, Sreedhar T., Venky Panchapegasan, and Ingrid Werner. 2007. The Changing Nature of Chapter 11. Fisher College of Business Working Paper No. 2008-03-003. http://ssrn.com/abstract=1102366.

Bradley, Michael and Michael Rosenzweig. 1992. The Untenable Case for Chapter 11. Yale L.J. 101:1043-1089.

Broadie, Mark, Mikhail Chernov, and Suresh Sundaresan. 2007. Optimal Debt and Equity Values in the Presence of Chapter 7 and Chapter 11. J. Fin 62:1341-1377.

Carapeto, Maria. 2003. Does Debtor-in-Possession Financing Add Value? Working paper. Cass Business School. 
Chatterjee, Sris, Upinder S. Dhillon and Gabriel G. Ramirez. 2004. Debtorin-Possession Financing. J. Bank. \& Fin. 28:3097-3111.

Dahiya, Sandeep, Kose John, Manju Puri, and Gabriel Ramirez. 2003. Debtor-in-Possession Financing and Bankruptcy Resolution: Empirical Evidence. J. Fin. Econ. 69:259-280.

Dhillon, Upinder S., Thomas Noe, and Gabriel Ramirez. 1996. Debtor-inPossession Financing and the Resolution of Uncertainty in Chapter 11 Reorganizations. Working paper . http://ssrn.com/abstract $=6301$.

Elayan, Fayez A. and Thomas O. Meyer. 2001. The Impact of Receiving Debtor-in-Possession Financing on the Probability of Successful Emergence and Time Spent under Chapter 11 Bankruptcy. J. Bus. Fin. \& Acctg. 28:905-942.

Fisher, Eric B. and Andrew L. Buck. 2007. Hedge Funds and the Changing Face of Corporate Bankruptcy Practice. Am. Bankr. Inst. J. 25-Jan:24.

Fortgang, Chaim J. and Thomas M. Mayer. 1990. Trading Claims and Taking Control of Corporations in Chapter 11. Cardozo L. Rev. 12:1-115.

Francois, Pascal and Erwan Morellec. 2004. Capital Structure and Asset Prices: Some Effects of Bankruptcy Procedures. J. Bus. 77:387-411.

Franks, Julian and Oren Sussman. 2005. Financial Distress and Bank Restructuring of Small to Medium Size UK Companies. Rev. Fin. 9:65-96.

Gertner, Robert and Randal C. Picker. 1992. Bankruptcy and the Allocation of Control. Working paper.

Gilson, Stuart C. 1989. Management Turnover and Financial Distress. J. Fin. Econ. 25:241-262.

Gilson, Stuart C. and Michael R. Vetsuypens. 1994. Creditor Control in Financially Distressed Firms: Empirical Evidence. Wash. U. L. Q. 72:1005-1025. Goldschmid, Paul M. 2005. Note, More Phoenix than Vulture: The Case for Distressed Investor Presence in the Bankruptcy Reorganization Process. Colum. Bus. L. Rev. 2005:191-274.

Imbs, Jean and Romain Wacziarg. 2003. Stages of Diversification. Am. Econ. Rev. 93:63-86.

Jensen, Michael C. and William H. Meckling. 1976. Theory of the Firm: Managerial Behavior, Agency Costs, and Ownership Structure. J. Fin. Econ. 3:305-360.

Kaplan, Steven N. and Bernadette A. Minton. 2006. How Has CEO Turnover Changed? Increasingly Performance Sensitive Boards and Increasingly Uneasy CEOs. NBER Working Paper No. 12465. http://www.nber. org/papers/w12465. 
LoPucki, Lynn. 2003. The Nature of the Bankrupt Firm: A Response to Baird and Rasmussen's The End of Bankruptcy. Stan. L. Rev. 56:645-671.

LoPucki, Lynn M. and Joseph W. Doherty. 2007. Bankruptcy Fire Sales. Mich. L. Rev. 106:1-58.

LoPucki, Lynn M. and William C. Whitford. 1993. Corporate Governance in the Bankruptcy Reorganization of Large, Publicly Held Companies. U. Penn. L. Rev. 141:669-800.

McGlaun, Greg. 2007. Lender Control in Chapter 11: Empirical Evidence. Working paper. University of Rochester. http://ssrn.com/ abstract $=961365$.

Miller, Harvey R. and Shay Y. Waisman. 2004. Does Chapter 11 Reorganization Remain a Viable Option for Distressed Businesses For the TwentyFirst Century? Am. Bankr. L. J. 78:153-200.

Partnoy, Frank and David Skeel. 2007. The Promise and Perils of Credit Derivatives. U. Cin. L. Rev. 75:1019-1051.

Pulvino, Todd. 1998. Do Asset Fire Sales Exist? An Empirical Investigation of Commercial Aircraft Transactions. J. Fin. 53:939-978.

Schwartz, Alan. 1997. A Contract Theory Approach to Business Bankruptcy. Yale L.J. 107:1807-1851.

Shleifer, Andrei and Robert W. Vishny. 1992. Liquidation Values and Debt Capacity: A Market Equilibrium Approach. J. Fin. 47:1343-1366.

Sibilkov, Valeriy. 2007. Asset Liquidity and Capital Structure. Working paper. University of Wisconsin-Milwaukee. http://ssrn.com/abstract=594523.

Skeel, David. 2003. Creditor's Ball: The "New" New Corporate Governance in Chapter 11. U. Penn. L. Rev. 152:917-951.

Skeel, David A. 2004. The Past, Present and Future of Debtor-in-Possession Financing. Cardozo L. Rev. 25:1905-1934.

Stromberg, Per. 2000. Conflicts of Interest and Market Illiquidity in Bankruptcy Auctions: Theory and Tests. J. Fin 55:2641-2692.

Tung, Frederick. 1996. Confirmation and Claims Trading. Nw. L. Rev. 90:1684-1754.

Warren, Elizabeth and Jay Westbrook. 2003. Secured Party in Possession. Am. Bankr. Inst. J. 22-Sep:12, 52-53.

Weiss, Lawrence A. 1990. Bankruptcy Resolution: Direct Costs and Violation of Priority of Claims. J. Fin. Econ. 27:285-314. 


\section{APPENDIX A: FORMAL MODEL}

Consider a firm that has recently filed for bankruptcy. We will refer to the bankruptcy filing date as date 0 . The firm faces a simple decision: whether to conduct an immediate sale, or wait and reorganize.

If the firm chooses to sell immediately at date 0 , a value $X$ will be realized, which is known by all participants. If it instead chooses to wait, the future value of the firm when the reorganization plan is confirmed (call this date 1) might increase or decrease from its value on the filing date. Suppose that with probability $p$ the firm's value increases to $u X$ by date 1 , where $u>1$. With probability (1-p), the firm's value decreases to $d X$, where $d<1$. We focus on parameter values such that $u X>F>d X$. Assuming a discount rate of zero, it is value-maximizing to reorganize if and only if

$$
G(p)=p u+(1-p) d>1
$$

Or, equivalently, the threshold probability $p_{e}$ above which reorganization is value-maximizing is given by $p_{e}=(1-d) /(u-d)$.

We suppose that $p$ is random and, for simplicity, distributed uniformly over the interval $[0,1]$. This implies that it is efficient to sell and to reorganize the firm with positive probability, depending on the realization of $p$. Social efficiency is not guaranteed because parties who exert influence over the decision might have incentives that are distorted by their position in the capital structure.

For simplicity, we focus on the conflict between senior and junior creditors, supposing that equity is sufficiently "out of the money" that their interests will be extinguished in all possible outcomes. This makes the junior creditors the residual claimants in the bankruptcy process. Distributions will be made according to priority: The secured creditor will receive the first $F$ dollars of any realized value, with unsecured creditors receiving the remainder if any exists.

Suppose the senior creditors have allowed claims worth $F$, secured by all the firm's assets. We say that secured creditors are oversecured if $F / X<1$ and undersecured if $F / X>1$. We suppose that bankruptcy outcomes will be determined as follows: Management will pursue the efficient outcome unless the secured creditor attempts to force a sale. For concreteness, we suppose the secured creditor does this by making a motion to lift the automatic stay, though other methods of creditor control apply as well (such as including 
covenants in the DIP loan that force the firm to find a buyer). If the judge grants the motion, the secured creditor will be able to seize its collateral. We assume that if this occurs, management will agree to sell the firm in advance of the seizure of collateral, knowing that it has no hope of reorganizing. The sale could be a going-concern or piece-meal sale of assets, as either interpretation is consistent with the model.

We assume that the judge's decision to lift the stay depends on the amount owed to the secured creditor, as well as the sale $(X)$ and reorganization values of the firm $(G(p) X)$. Specifically, the probability that the judge grants a motion to lift the stay is a function of the following ratio:

$$
K=\min \{F, X\} /(G(p) X)
$$

We denote the probability of approving the motion to lift the stay as $L(K)$ and assume it is always strictly between 0 and 1 . We also assume, importantly, that $L(K)$ is increasing in $K$, which is consistent with the bankruptcy code. To see this, note that the numerator of $K, \min \{F, X\}$, represents the secured portion of the creditor's claim, which is entitled to "adequate protection" under the Bankruptcy code (11 u.s.c. $\$ 361$ ). A secured creditor is generaly entitled to compensation ("adequate protection") to the extent that a firm's use of collateral results in depreciation of the value of the collateral. The denominator of $K, G(p) X$, is the expected reorganization value of the firm. If $\min \{F, X\}$ is low relative to $G(p) X$, it is likely that the secured creditor's collateral is protected from a decline in value, and hence the judge will be less likely to find an absence of adequate protection. Conversely, as $\min \{F, X\}$ approaches $G(p) X$, a greater likelihood exists that the secured creditor's claim will decline in value in the reorganization process, increasing the likelihood that the judge will find an absence of adequate protection.

We now analyze the probability of reorganization as a function of $F / X$, depending on whether the secured creditor is oversecured or undersecured.

\section{Case 1: Secured Creditors Are Oversecured: F/X $<1$}

When secured creditors are oversecured, they will always make a motion to lift the stay in an attempt to force a sale, if management does not propose a sale itself. To see this, note that if the firm is sold, the secured creditor receives $F$. If the firm is reorganized, the secured creditor receives $p F+(1-p) d X$, which is always strictly less than $F$, since $d X<F$. Thus, 
using our assumption that $p$ is distributed uniformly between 0 and 1 , the probability that reorganization occurs when the secured creditor is oversecured is

$$
\operatorname{Pr}(\text { reorg, over })=1-p_{e}-\int_{p_{e}}^{1} L(K) d p .
$$

The second term in the expression, $p_{e}$, is the probability that a sale is efficient (this follows from our assumption that $p$ is distributed uniformly). The manager voluntarily chooses an efficient sale. The third term is the probability that the judge approves a secured creditor motion to liquidate, conditional on management preferring reorganization. Note that in the oversecured case, $K=F /(G(p) X)$. Thus, the integral is strictly increasing in $F / X$, since $L(K)$ is increasing in $K$, and $K$ is increasing in $F / X$ for all $p$ between 0 and 1 . This implies that $\operatorname{Pr}$ (reorg, over) is strictly decreasing in $F / X$ when the secured creditor is oversecured.

\section{Case 2: Secured Creditors Are Undersecured: F/X >1}

Unlike Case 1, if the secured creditor is oversecured, it might favor a reorganization if $p$ is sufficiently high. This will be the case if and only if

$$
X<p F+(1-p) d X
$$

Rearranging this expression, the threshold probability $p^{\star}$ above which the secured creditor prefers a reorganization is given by $p^{*}=(1-d) /(F / X-d)$. This threshold is decreasing in $F / X$, implying that as the secured creditor becomes more undersecured, it will favor reorganization for a larger fraction of firms. Using our assumption that $p$ is distributed uniformly, the probability of reorganization is

$$
\operatorname{Pr}(\text { reorg, under })=1-p_{e}-\int_{p_{e}}^{p^{*}} L(K) d p .
$$

In the undersecured case, $K=1 / G(p)$. Thus, $K$ does not depend on $F / X$, but the threshold $p^{*}$ is decreasing in $F / X$ and $L(K)$ is strictly positive for all $p$. Thus, the value of the integral is strictly decreasing in $F / X$, implying that the probability of reorganization is increasing in $F / X$. Note that as $F / X$ approaches $u$ (meaning the secured creditor becomes the full residual claimant), $p_{e}$ approaches $p^{*}$, making the value of the integral zero and the probability of reorganization simply $1-(1-d) /(u-d)$. 


\section{Case 3: No Secured Debt}

When no secured creditor exists to file a motion to lift the stay, reorganization will occur if and only if it is efficient. Thus, the probability of reorganization is simply $\operatorname{Pr}($ reorg, no $)=1-(1-d) /(u-d)$. Note that this probability is the same as the upper limit in Case 2, where the secured creditor is maximally undersecured.

Our analysis has shown that the probability of reorganization is strictly decreasing in $F / X$ for $F / X<1$, and strictly increasing in $F / X$ for $F / X>1$. Finally, note that when $F=X$ (when the secured creditor is neither undernor oversecured), $\operatorname{Pr}$ (reorg, over) and $\operatorname{Pr}$ (reorg, under) are equal, since $p^{*}=1$. Thus, the model predicts that the probability of reorganization is non-monotonic in $F / X$, is minimized at $F=X$, and is maximized in the cases where no secured debt exists and where the undersecured creditor becomes the full residual claimant. 


\section{APPENDIX B: FULL SAMPLE AND SAMPLE INCLUDED IN PROBIT REGRESSIONS}

\begin{tabular}{|c|c|c|c|}
\hline Firm Name & Court & Filing Date & $\begin{array}{l}\text { Included in } \\
\text { Regressions? }\end{array}$ \\
\hline eBiz Enterprises, Inc. & $A Z$ & $9 / 7 / 2001$ & Yes \\
\hline Southwest Supermarkets LLC & $A Z$ & $11 / 5 / 2001$ & Yes \\
\hline FourthStage Technologies, Inc. & $A Z$ & $12 / 31 / 2001$ & Yes \\
\hline Fountain View, Inc. & CDCA & $10 / 2 / 2001$ & Yes \\
\hline Cohen Medical Corp (aka Tower Health) & CDCA & $10 / 4 / 2001$ & Yes \\
\hline House2Home, Inc. & CDCA & $11 / 8 / 2001$ & Yes \\
\hline Kushner-Locke International, Inc. & CDCA & $11 / 21 / 2001$ & Yes \\
\hline BMK, Inc. & CDCA & $12 / 3 / 2001$ & Yes \\
\hline Drkoop.com & CDCA & $12 / 17 / 2001$ & Yes \\
\hline GenSci Regeneration Sciences & CDCA & $12 / 20 / 2001$ & Yes \\
\hline Internet Commerce \& Communications & $\mathrm{CO}$ & $7 / 31 / 2001$ & \\
\hline North Lily Mining Co. & $\mathrm{CO}$ & $9 / 6 / 2001$ & \\
\hline NetLibrary* & $\mathrm{CO}$ & $11 / 14 / 2001$ & \\
\hline Amherst Reeves Worldwide, LLC & $\mathrm{CO}$ & $12 / 12 / 2001$ & \\
\hline Pensat, Inc. & DC & $10 / 9 / 2001$ & \\
\hline Ardent Communications, Inc. & DC & $10 / 10 / 2001$ & \\
\hline AxisTel (Novo Networks, Inc.) & DE & $7 / 30 / 2001$ & Yes \\
\hline Intira Corp. & DE & $7 / 30 / 2001$ & Yes \\
\hline DIMAC Direct, Inc. & DE & $8 / 2 / 2001$ & Yes \\
\hline Mosler, Inc. & $\mathrm{DE}$ & $8 / 6 / 2001$ & Yes \\
\hline Covad Communications & DE & $8 / 15 / 2001$ & Yes \\
\hline Derby Cycle Corp. & DE & $8 / 20 / 2001$ & Yes \\
\hline Steel Heddle Group, Inc. & DE & $8 / 28 / 2001$ & Yes \\
\hline U.S. Wireless Corp. & $\mathrm{DE}$ & $8 / 29 / 2001$ & Yes \\
\hline Breakaway Solutions, Inc. & DE & 9/5/2001 & Yes \\
\hline American Tissue, Inc. & DE & $9 / 10 / 2001$ & Yes \\
\hline Family Wonder Holdings, LLC & $\mathrm{DE}$ & 9/10/2001 & Yes \\
\hline McCrory Corp. & $\mathrm{DE}$ & $9 / 10 / 2001$ & Yes \\
\hline MCMS, Inc. & $\mathrm{DE}$ & $9 / 18 / 2001$ & Yes \\
\hline International Knife \& Saw, Inc./IKS Corp. & DE & $9 / 24 / 2001$ & \\
\hline
\end{tabular}




\begin{tabular}{|c|c|c|c|}
\hline Firm Name & Court & Filing Date & $\begin{array}{l}\text { Included in } \\
\text { Regressions? }\end{array}$ \\
\hline Exodus Communications, Inc. & $\mathrm{DE}$ & $9 / 26 / 2001$ & Yes \\
\hline Assisted Living Concepts, Inc. & DE & $10 / 1 / 2001$ & Yes \\
\hline Federal-Mogul Global, Inc. & $\mathrm{DE}$ & $10 / 1 / 2001$ & Yes \\
\hline iBEAM Broadcasting Corp. & DE & 10/11/2001 & Yes \\
\hline Polaroid Corp. & DE & $10 / 12 / 2001$ & Yes \\
\hline Net2000 Communications, Inc. & $\mathrm{DE}$ & $10 / 16 / 2001$ & Yes \\
\hline VecTour, Inc. & $\mathrm{DE}$ & $10 / 16 / 2001$ & Yes \\
\hline American Classic Voyages, Inc. & DE & $10 / 19 / 2001$ & Yes \\
\hline United Petroleum Corp. & $\mathrm{DE}$ & $10 / 30 / 2001$ & \\
\hline General Datacomm Industries, Inc. & $\mathrm{DE}$ & $11 / 3 / 2001$ & Yes \\
\hline ANC Rental Corp. & $\mathrm{DE}$ & $11 / 13 / 2001$ & Yes \\
\hline Classic Communications, Inc. & DE & $11 / 14 / 2001$ & Yes \\
\hline Global Telesystems, Inc. & DE & $11 / 14 / 2001$ & Yes \\
\hline Burlington Industries, Inc. & $\mathrm{DE}$ & $11 / 15 / 2001$ & Yes \\
\hline Sleepmaster LLC & $\mathrm{DE}$ & $11 / 20 / 2001$ & Yes \\
\hline Valley Media, Inc. & $\mathrm{DE}$ & $11 / 20 / 2001$ & Yes \\
\hline Hayes Lemmerz International, Inc. & DE & $12 / 5 / 2001$ & Yes \\
\hline Lason, Inc. & $\mathrm{DE}$ & $12 / 5 / 2001$ & Yes \\
\hline NationsRent, Inc. & $\mathrm{DE}$ & $12 / 17 / 2001$ & Yes \\
\hline Greate Bay Casino Corp. & $\mathrm{DE}$ & $12 / 28 / 2001$ & Yes \\
\hline Wavve Telecommunications & EDCA & $8 / 15 / 2001$ & Yes \\
\hline W.R. Carpenter North America, Inc. & EDCA & $12 / 31 / 2001$ & Yes \\
\hline NetVoice Technologies, Inc. & EDLA & $10 / 17 / 2001$ & Yes \\
\hline Global Technovations, Inc. & EDMI & $12 / 18 / 2001$ & \\
\hline Thermadyne Holdings Corp. & EDMO & $11 / 19 / 2001$ & Yes \\
\hline Digital Teleport/DTI Holdings, Inc. & EDMO & $12 / 31 / 2001$ & Yes \\
\hline Midway Airlines Corp. & EDNC & $8 / 13 / 2001$ & \\
\hline International Total Services, Inc. & EDNY & $9 / 13 / 2001$ & \\
\hline Cyberedge Enterprises & EDNY & $10 / 1 / 2001$ & \\
\hline Burpee Holding Co. & EDPA & $9 / 21 / 2001$ & \\
\hline Wheland Manufacturing Co. & EDTN & $11 / 7 / 2001$ & \\
\hline Nx Networks, Inc. & EDVA & $11 / 2 / 2001$ & \\
\hline
\end{tabular}




\begin{tabular}{|c|c|c|c|}
\hline Firm Name & Court & Filing Date & $\begin{array}{l}\text { Included in } \\
\text { Regressions? }\end{array}$ \\
\hline Worden, Inc. & EDWA & $12 / 7 / 2001$ & Yes \\
\hline Aquasearch, Inc. & $\mathrm{HI}$ & $10 / 29 / 2001$ & Yes \\
\hline Aztec Technology Partners, Inc. & MA & $10 / 5 / 2001$ & \\
\hline Arch Wireless, Inc. & MA & $12 / 6 / 2001$ & Yes \\
\hline ACT Manufacturing, Inc. & MA & $12 / 21 / 2001$ & \\
\hline Railworks Corp. & MD & $9 / 20 / 2001$ & \\
\hline Startec Global Communications Corp. & MD & $12 / 14 / 2001$ & \\
\hline GRG, Inc. & MDFL & $8 / 7 / 2001$ & \\
\hline World Commerce Online Inc. & MDFL & $8 / 20 / 2001$ & \\
\hline Planet Hollywood International, Inc. & MDFL & $10 / 19 / 2001$ & \\
\hline ThermaCell Technologies, Inc. & MDFL & $11 / 7 / 2001$ & \\
\hline Transit Group, Inc. & MDFL & $12 / 28 / 2001$ & \\
\hline BuildNet, Inc. & MDNC & $8 / 8 / 2001$ & Yes \\
\hline PHICO Group, Inc. & MDPA & $12 / 14 / 2001$ & Yes \\
\hline Regal Cinemas, Inc. & MDTN & $10 / 12 / 2001$ & Yes \\
\hline Phoenix Restaurant Group, Inc. & MDTN & $11 / 2 / 2001$ & Yes \\
\hline Wall Street Deli, Inc. & NDAL & $10 / 1 / 2001$ & \\
\hline VelocityHSI, Inc. & NDCA & $8 / 14 / 2001$ & \\
\hline At Comm Corp. & NDCA & $8 / 15 / 2001$ & \\
\hline Egghead.com & NDCA & $8 / 15 / 2001$ & \\
\hline Centura Software Corp., aka Mbrane & NDCA & $8 / 21 / 2001$ & \\
\hline Komag Inc. & NDCA & $8 / 24 / 2001$ & \\
\hline Enlighten Software Solutions, Inc. & NDCA & $9 / 13 / 2001$ & \\
\hline At Home Corporation, aka Excite @home & NDCA & $9 / 28 / 2001$ & \\
\hline Netcentives, Inc. & NDCA & $10 / 5 / 2001$ & \\
\hline HealthCentral.com & NDCA & $10 / 9 / 2001$ & \\
\hline Mayan Networks Corp. & NDCA & $11 / 6 / 2001$ & \\
\hline ATG, Inc. & NDCA & $12 / 3 / 2001$ & \\
\hline OmniSky Corp. & NDCA & $12 / 10 / 2001$ & \\
\hline Calico Commerce, Inc. & NDCA & $12 / 14 / 2001$ & \\
\hline Dialpad Communications, Inc. & NDCA & $12 / 19 / 2001$ & \\
\hline Ha-Lo Industries, Inc. & NDIL & $7 / 30 / 2001$ & Yes \\
\hline
\end{tabular}




\begin{tabular}{|c|c|c|c|}
\hline Firm Name & Court & Filing Date & $\begin{array}{l}\text { Included in } \\
\text { Regressions? }\end{array}$ \\
\hline Cytomedix, Inc. & NDIL & $8 / 7 / 2001$ & Yes \\
\hline Sames Corp. & NDIL & $8 / 17 / 2001$ & \\
\hline ABC-NACO, Inc. & NDIL & $10 / 18 / 2001$ & Yes \\
\hline Advance Mixer, Inc. & NDIN & $12 / 12 / 2001$ & \\
\hline Semiconductor Laser International Corp. & NDNY & $10 / 18 / 2001$ & \\
\hline Planet Entertainment Corp. & NDNY & $11 / 30 / 2001$ & \\
\hline Phar-Mor, Inc. & $\mathrm{NDOH}$ & $9 / 24 / 2001$ & Yes \\
\hline Nesco, Inc. & NDOK & $11 / 26 / 2001$ & Yes \\
\hline Sheffield Steel Corp. & NDOK & $12 / 7 / 2001$ & Yes \\
\hline Stonebridge Technologies, Inc. & NDTX & $9 / 6 / 2001$ & \\
\hline NAB Asset Corp. & NDTX & $9 / 26 / 2001$ & \\
\hline Alford Refridgerated Warehouses, Inc. & NDTX & $11 / 6 / 2001$ & \\
\hline CoServ, LLC & NDTX & $11 / 30 / 2001$ & \\
\hline Adesta Communications, Inc. & NE & $11 / 3 / 2001$ & Yes \\
\hline Impower, Inc. & NJ & $8 / 3 / 2001$ & Yes \\
\hline Infu-Tech, Inc. & NJ & $8 / 21 / 2001$ & Yes \\
\hline Response USA, Inc. & NJ & $8 / 30 / 2001$ & Yes \\
\hline Aladdin Gaming, LLC & NV & $9 / 28 / 2001$ & \\
\hline Decision Link, Inc. & NV & $12 / 6 / 2001$ & Yes \\
\hline UCI Medical Affiliates, Inc. & SC & $11 / 3 / 2001$ & \\
\hline Anacomp, Inc. & SDCA & $10 / 19 / 2001$ & Yes \\
\hline Tri-National Development Corp. & SDCA & $10 / 23 / 2001$ & Yes \\
\hline Vitech America, Inc. & SDFL & $8 / 17 / 2001$ & \\
\hline Amerijet International, Inc. & SDFL & $8 / 22 / 2001$ & \\
\hline Renaissance Cruises, Inc. & SDFL & $9 / 25 / 2001$ & \\
\hline Viasource Communications, Inc. & SDFL & $11 / 15 / 2001$ & \\
\hline Rhythms NetConnections, Inc. & SDNY & $8 / 1 / 2001$ & \\
\hline AccuHealth, Inc. & SDNY & $8 / 10 / 2001$ & Yes \\
\hline FutureLink Corporation & SDNY & $8 / 14 / 2001$ & Yes \\
\hline Ames Department Stores, Inc. & SDNY & $8 / 20 / 2001$ & Yes \\
\hline DelSoft Consulting, Inc. & SDNY & $8 / 31 / 2001$ & Yes \\
\hline Dairy Mart Convenience Stores, Inc. & SDNY & $9 / 24 / 2001$ & Yes \\
\hline
\end{tabular}




\begin{tabular}{|c|c|c|c|}
\hline Firm Name & Court & Filing Date & $\begin{array}{l}\text { Included in } \\
\text { Regressions? }\end{array}$ \\
\hline Cygnifi Derivatives Services & SDNY & $10 / 3 / 2001$ & Yes \\
\hline Swissair Group, Inc. & SDNY & 10/9/2001 & Yes \\
\hline Bethlehem Steel Corp. & SDNY & $10 / 15 / 2001$ & Yes \\
\hline eLOT, Inc. & SDNY & $10 / 15 / 2001$ & Yes \\
\hline HMG Worldwide Corp. & SDNY & $10 / 23 / 2001$ & Yes \\
\hline Virtual Growth, Inc. & SDNY & $12 / 13 / 2001$ & Yes \\
\hline Valeo Electrical Systems, Inc. & SDNY & $12 / 14 / 2001$ & Yes \\
\hline Audio Visual Services Corp. & SDNY & $12 / 17 / 2001$ & \\
\hline Lodgian, Inc. & SDNY & $12 / 20 / 2001$ & Yes \\
\hline Nations Flooring, Inc. & SDNY & $12 / 20 / 2001$ & Yes \\
\hline York Research Corp. & SDNY & $12 / 20 / 2001$ & Yes \\
\hline Genesis Worldwide, Inc. & $\mathrm{SDOH}$ & $9 / 17 / 2001$ & \\
\hline Spinnaker Industries, Inc. & $\mathrm{SDOH}$ & $11 / 13 / 2001$ & \\
\hline Chiquita Brands International, Inc. & $\mathrm{SDOH}$ & $11 / 28 / 2001$ & \\
\hline Pioneer Companies, Inc. & SDTX & $7 / 31 / 2001$ & \\
\hline PowerBrief Inc. & SDTX & $10 / 2 / 2001$ & \\
\hline Metals USA, Inc. & SDTX & $11 / 14 / 2001$ & Yes \\
\hline Luminant Worldwide Corp. & SDTX & $12 / 7 / 2001$ & Yes \\
\hline Arrow Dynamics, Inc. & UT & $12 / 3 / 2001$ & \\
\hline Quality Stores, Inc. & WDMI & $10 / 20 / 2001$ & Yes \\
\hline Trism, Inc. & WDMO & $12 / 18 / 2001$ & Yes \\
\hline Brylin Hospitals, Inc. & WDNY & $10 / 29 / 2001$ & \\
\hline Homeland Holding Corp. & WDOK & $8 / 1 / 2001$ & \\
\hline Edgewater Steel Ltd & WDPA & $8 / 6 / 2001$ & \\
\hline The Carbide/Graphite Group Inc. & WDPA & $9 / 21 / 2001$ & \\
\hline Tristar Corp. & WDTX & $8 / 8 / 2001$ & Yes \\
\hline Play By Play Toys \& Novelties, Inc. & WDTX & $11 / 1 / 2001$ & Yes \\
\hline Westar Financial Services & WDWA & $12 / 20 / 2001$ & Yes \\
\hline
\end{tabular}





\section{JLA | Journal of Legal Analysis}

Baron, Ritov, The Role of Probability of Detection in Judgments of Punishment

Summer, 2009: Volume 1, Number 2

This online journal is licensed under a Creative Commons

Attribution-Noncommercial-Share Alike 3.0 Unported License

http://jla.hup.harvard.edu 
